University of Nebraska - Lincoln

DigitalCommons@University of Nebraska - Lincoln

Sociology Department, Faculty Publications

Sociology, Department of

1988

\title{
Leadership and nonverbal behaviors of Hispanic females across school equity environments
}

\author{
Helen A. Moore \\ University of Nebraska-Lincoln, hmoore1@unl.edu \\ Natalie K. Porter \\ University of New Mexico
}

Follow this and additional works at: https://digitalcommons.unl.edu/sociologyfacpub

Part of the Bilingual, Multilingual, and Multicultural Education Commons, Inequality and Stratification Commons, Race and Ethnicity Commons, and the Social Psychology and Interaction Commons

Moore, Helen A. and Porter, Natalie K., "Leadership and nonverbal behaviors of Hispanic females across school equity environments" (1988). Sociology Department, Faculty Publications. 100.

https://digitalcommons.unl.edu/sociologyfacpub/100

This Article is brought to you for free and open access by the Sociology, Department of at DigitalCommons@University of Nebraska - Lincoln. It has been accepted for inclusion in Sociology Department, Faculty Publications by an authorized administrator of DigitalCommons@University of Nebraska - Lincoln. 


\title{
LEADERSHIP AND NONVERBAL BEHAVIORS OF HISPANIC FEMALES ACROSS SCHOOL EQUITY ENVIRONMENTS
}

\author{
Helen A Moore \\ University of Nebraska \\ Natalıe K Porter \\ University of New Mexico
}

\begin{abstract}
Nonverbal behaviors of Hispanic elementary school students and their peers were examıned in a small-group cooperatıve task with a total of 202 subjects Thırty-five randomly selected groups were videotaped in ten desegregated schools, each group was gender-homogeneous, with three Hispanic and three Anglo students Analysis of the videotapes revealed that Hispanic females used less vertical and horizontal space than Anglo females, and were also less likely to verbally interrupt or physically intrude on other group members They had similar rates of handlıng the group resource cards and were given sımılar leadershıp scores by multi-ethnic trained observers Among males, Hispanics are significantly more likely to use vertical or upward movements and physıcal intrusions, while Anglos use more verbal interruptıons

School and social status factors such as high- and low-equity desegregated school programs, ethnic and gender status, and school status variables of academic grades and Englısh word knowledge had varyıng effects on teacher and peer ratıngs of leadershıp High-equity schools garnered hıgher leadershıp scores for Hispanıc females from both peers and teachers when all other nonverbal behaviors were controlled This positive effect of the school on leadershıp ratıngs was evident only for males in
\end{abstract}

Portions of this research were funded by NIMH Public Health Research Grant No MH 2660703 and from a co-authored grant from the University of Nebraska, Lincoln, Faculty Research Councl The authors are indebted to Jane $R$ Mercer and Peter Iadicola for their work on the initial grant project An earher version of this paper was presented at the Annual Meeting of the American Sociological Association, August, 1987

Requests for reprints should be sent to Helen A Moore, Dept of Sociology, University of Nebraska, Lincoln, Nebraska 68588-0324 
teacher ratıngs Hispanic females and their peers do reflect adult models of nonverbal behavior and leadershıp, and that leadership is enhanced in the perceptions of teachers and peers when they participate in a highequity desegregated elementary school

Hispanic females in desegregated schools face contradictory social and educational expectations from the dominant Anglo core culture and from gender expectations in Hispanic family and community settungs (BacaZinn, 1985, Mirande \& Enriquez, 1979, Zapata \& Jaramillo, 1981) Many of these social and educational expectations are communicated nonverbally among peer groups and between teachers and students in the school setting In this research, we examined the variation in nonverbal behaviors among students and the relationship of those behaviors to ratings of their leadership We also focused on the expectations created for Hispanic female leadership in different school settings Among the school and social status factors we consider are vanous desegregated school environments, ethnic and gender status, and school status variables such as academic grades and English word knowledge scores All of these factors may influence the perceptions of Hispanic female leadership by their student peers and teachers

\section{NONVERBAL BEHAVIORS AND LEADERSHIP}

Leadership can be assessed on the basis of many factors In this research, we focused on school status factors (e $g$, grade point average, English word knowledge, and peer rankings prior to the game), and nonverbal behaviors exhibited in a multi-ethmic interaction game Nonverbal behaviors take on shared meanings in a specific cultural setting (Henley, 1977) These nonverbal behaviors appear to influence a group's assignment of status and leadership as much as verbal elements of group interaction or attractiveness Some researchers suggest that the nonverbal channels of communication can be more influential than verbal channels (Mehrabian, 1972)

Several nonverbal behaviors studied in adults have been found to be associated with leadership and status within groups Individuals of higher status use more personal space (Mehrabian, 1972), touch more and intrude more into others' personal space (Henley, 1973) High status individuals in general yield their positions less and occupy more central positions in a group (Baxter, 1970) Schwartz, Tesser, and Powell (1982) found that elevation is the strongest predictor of social dominance, whle lateral placement and other postures were less influential predictors Individuals perceived as leaders by others tend to talk more (Strodtbeck \& Mann, 1956) and interrupt more (Zimmerman \& West, 1975) The latter two behaviors are class1- 
fied in this study as "nonverbal" because we are interested in rates of behavior, as opposed to the content of the verbal interactions

These nonverbal behaviors appear to be learned, and tend to vary with gender, social status, and race or ethnic background (Henley, 1977, Mayo \& Henley, 1981) Among adults, males are generally more dominant and display higher status on a nonverbal level (Frieze \& Ramsey, 1976) Men use more space with their arms and legs, make wider stretching gestures, and more gestures, than do women (Aries, 1982, Pearson, 1985) Men also rely on more open body positions to show authority and ease (Henley, 1977) Men touch others (Henley, 1977) and verbally interrupt others more than women do (Zimmerman \& West, 1975) In contrast, women use a "restricted" personal space, and engage in more self-touching behaviors, which contributes to lower status in interactions (Henley, 1977)

Aiello and Jones (1971) identified gender and ethnic differences among Anglo, Black, and Puerto Rican first- and second-grade children in a study of proxemic behavior, including interaction distances and directness of shoulder onentation Middle-class Anglos stood further apart than minority students Significant sex differences were found only among Anglos, with males standing further apart than females The authors concluded that these nonverbal patterns are acquired early in life and demonstrate significant differences between the dominant culture and minority cultures in the use of space Jones (1971) found that females of each of three ethnic groups, Black, Anglo, and Puerto Rican, stood closer together than their male ethnic peers

\section{SCHOOL EQUITY AND LEADERSHIP}

We can set the context of these nonverbal behaviors and the leadership associated with them within an equal status relations model of schools This model assumes that any status order in the larger society can create expectations about the competence of certain status groups (males vis-à-vis females, Hispanic vis-à-vis Anglo) which are accepted by all groups (Berger, Rosenholtz, \& Zelditch, 1980) Simllarly, status order in the larger society may lead to differential evaluation of leadership within a particular school setting When members of status groups interact, expectations for leadership may lead to dominance or influence by the higher ranked groups The equal status relations model proposed by Berger, Conner, and Fisek (1974) identifies the relationship of gender and ethnicity to the expectations of significant others in a society An individual's status order in the larger society (gender, ethnicity, or age) creates expectations about competence, which in turn may affect educational and interpersonal outcomes These expectations, skills, and behaviors may vary across status groups and across educational settings

Educational research on interracial and mixed academic status groups 
consistently has shown that higher status children tend to be more active and influential than lower status children (Cohen, 1984) Both race and gender act as diffuse status characteristics that maintain status inequalities in the schools

\section{High Equity Schools}

A variety of experimental and survey studies have identified factors and interventions which can create more equal status interactions within institutions (Mercer, Iadicola, \& Moore, 1980) Rosenfield and Stephan (1981) identified variations in school desegregation factors that reduce negative stereotypes of minorities and enhance equal status contact, including desegregation of teaching staff, large proportions of minorities in desegregated classrooms, and admınıstratıve support of programs Johnson, Johnson, and Maruyama (1984) established through a meta-analysis of school research that cooperation in the classroom, as opposed to competition and individualısm, promotes greater interracial interpersonal attraction and equal status relations

Simoniello (1981) looked at both famly structure and school settings to identify factors that affect passivity and assertiveness among Hispanic females She argued that a key factor is a close relationship to the family, and access to informal mentoring in schools Depending upon such school factors, "a closed, male-dominated family can foster an independent, goal and achievement oriented woman, or a non-assertive, dependent, noncompetitive woman" (Simoniello, 1981, p 134)

Iadicola and Moore (1983) showed that access to multicultural curniculum, minority parental power in the school, and larger proportions of minority students and faculty increases the probability of Hispanic males and females moving to higher status positions in small group interactions In schools where equal status relationships are not supported, research consistently has shown that status rankings of students by teachers and peers place Anglo females and Chicano males lower than Anglo males, and Chicanas at the bottom of the status hierarchy (Moore, 1983)

Ethnic and gender differences in leadership and nonverbal behaviors may be mediated by the cultural context, the school settıng, in which these take place Those educational factors that influence the nonverbal behaviors of Chicanas, Chicanos and Anglos may also contribute to variations in the perceived leadership of these students

\section{HYPOTHESES}

1 Males and Anglos will score higher than females and Hispanics on dominance measures use of vertical and horizontal space, verbal interruptions, physical intrusions, speaking time, and touching of game cards Females and Hispan- 
ics will score higher on use of self-touching behaviors The former nonverbal behaviors will be associated with higher leadership scores Self-touching behaviors will be associated with lower leadership scores

2 Leadership Ratıngs will be more affected by target gender and ethnicity than nonverbal behavior ratıngs

3 Chicanos and Chicanas in high equity schools will be given higher leadership ratings than those in low equity schools

\section{METHOD}

Durnng the 1975-1976 school year, 10 desegregated schools participated in an intensive study of school environments and student outcomes These schools were selected from a sample of 184 elementary schools that had scored at the highest end of the continuum on a series of educational achievement, self-esteem and positive ethnic identity factors for Hispanic students ( 5 schools), and schools that had scored at the lowest end of that contınuum (5 schools) (see Iadicola, Lewis, Moore, \& Nickles, 1978, for a description of these factors) These schools were then evaluated for status equity conditions (multicultural curriculum, staff, parental involvement, testıng/tracking, and others) The high-equity schools scored significantly higher than the low-equity schools on administrative support of desegregation and multicultural curricula, and had higher proportions of minority staff and minority parent involvement (Iadicola \& Moore, 1983)

Information on the school environment was collected from administrators, student records, faculty, staff, and parent interviews and observations by trained personnel Information on the students was collected from their teachers, parents, student files, student questionnaires, and from videotaped interactions which were later coded by trained personnel Subsequently, 202 Anglo and Hispanic students were randomly selected from the third and sixth grade for videotaping

A total of 35 groups were videotaped interacting in a cooperative group game, Space Station Pegasus The game took place at a round game board, with resource cards representing materials needed by a stranded crew (see Iadicola \& Moore, 1983, for a detalled description of the game) Each group was composed of six children of the same gender and grade, with three Anglo students and three Hispanic students We chose to use all same-sex groups to observe behaviors when leadership positions are equally avalable to both males and females As Lockheed (1976) demonstrated, leadership among school-aged females is suppressed by the presence of male peers of any ability level Ridgeway (1987) also identified gender as a potentially confounding factor in measurng nonverbal behaviors in a task group

Each videotape was coded three times by trained staff of both sexes and from varied ethnic groups (two Hispanic, two Black and two Anglo of each sex) Coders were randomly assigned to students across groups and seatıng 
positions In 1978, a multi-ethnic staff used a bipolar semantic differential to rate students on global leadership (see Iadıcola \& Moore, 1983) In 1985, a new set of multi-ethnic staff timed or counted a series of verbal and nonverbal behaviors and interactions

\section{Nonverbal Varıables}

The following items were coded three times, each time by a randomly assigned coder (correlation coefficient for inter-rater reliability indicated in parentheses) number of seconds speaking ( 87 ), seconds touching the resource cards ( 81 ), seconds using more horizontal space than $1 / 6$ of the table ( 86), seconds using upward vertical space, including standing up ( 85), number of physical intrusions, including touching or hitting others (67), number of verbal interruptions directed at other students (72), and seconds engaged in self-touching behaviors ( 76) The student was assigned the mean of the three scores

The total average group interaction time varied significantly between male and female groups Females interacted for a mean time of 3 minutes and 58 seconds, whereas male groups interacted a mean time of 3 minutes and 33 seconds To control for these group differences, students' individual behavior scores were divided by their group time for a weighted factor which is used in the final analyses In Table 1, both the raw and weighted scores are presented separately for ethnic and gender groups

\section{Leadership Varıables}

The leadership variables consist of the student group members' ratings of each other after the interaction, observers' ratıngs of leadershıp during the interaction and the classroom teachers' rating of generalızed student leadership The student leadership rating was a count of the number of votes recelved by a student at the end of the game as "the student who most influenced the game" Observers rated each of the students on the following 11 semantic differentials which had a range of 1 to 7 (inter-rater reliability coefficient, 94) submissive/dominant, non-directıng/directing, follows/initiates, unopinıonated/opinıonated, indecisive/decisive, $\mathrm{rgid} / \mathrm{in}$ novative, nonmanıpulatıve/manipulative, nonorganizıng/organızıng, complacent/demanding, introverted/extroverted, and ineffective/effective (See Iadicola \& Moore, 1983, for factor loadings on these adjective pairs )

Classroom teachers completed survey ratings on a series of bipolar adjectives to describe each student in their classroom, including a leadership factor Teachers rated each student using the following adjective pairs. quick/slow, leads/follows, intelligent/dull-minded, able to concentrate/ subject to distraction, organized/disorganized, good memory/poor memory, persevering/quittıng, Reliablity for this teacher scale was 93 (See Iadicola \& Moore, 1983, for factor loadings ) 
Table 1

Mean raw and weighted nonverbal behavior scores

One-way analysis of variance by ethnicity

\begin{tabular}{|c|c|c|c|c|c|c|}
\hline \multirow[b]{2}{*}{ Behaviors } & \multicolumn{3}{|c|}{ Males } & \multicolumn{3}{|c|}{ Females } \\
\hline & Anglo & Hespanic & $F$ & Anglo & Hispanic & $F$ \\
\hline $\begin{array}{l}\text { Physical intrusions } \\
\text { (counted) }\end{array}$ & 275 & 359 & $567^{*}$ & 258 & 205 & 069 \\
\hline Weighted score & 163 & 214 & $708^{* *}$ & 143 & 117 & 118 \\
\hline $\begin{array}{l}\text { Verbal interruptions } \\
\text { (counted) }\end{array}$ & 405 & 295 & $368 *$ & 417 & 217 & $725^{* *}$ \\
\hline Weighted score & 192 & 157 & $512^{*}$ & 190 & 113 & $660 * *$ \\
\hline $\begin{array}{l}\text { Upward movement } \\
\text { (timed) }\end{array}$ & 1002 & 2416 & $425^{*}$ & 3358 & 702 & $653^{* *}$ \\
\hline Weighted score & 841 & 1152 & 159 & 920 & 424 & $477^{*}$ \\
\hline $\begin{array}{l}\text { Horizontal movement } \\
\text { (timed) }\end{array}$ & 4286 & 5390 & 168 & 4832 & 3883 & 172 \\
\hline Weighted score & 2389 & 3025 & $503^{*}$ & 2352 & 1886 & $414^{*}$ \\
\hline $\begin{array}{l}\text { Self-comfort } \\
\text { (timed) }\end{array}$ & 2652 & 2938 & 066 & 1326 & 787 & 152 \\
\hline Weighted score & 991 & 1024 & 034 & 454 & 341 & 014 \\
\hline Speakıng time & 2916 & 2768 & 088 & 3731 & 3038 & 287 \\
\hline Weighted score & 1482 & 1308 & 136 & 1409 & 1218 & 152 \\
\hline $\begin{array}{l}\text { Resource cards } \\
\text { (timed) }\end{array}$ & 3889 & 4870 & 169 & 3157 & 4739 & $327^{*}$ \\
\hline Weighted score & 2022 & 2825 & 221 & 1953 & 1990 & 004 \\
\hline $\begin{array}{l}\text { Average group time } \\
\text { (seconds) }\end{array}$ & & 21337 & & & 23838 & \\
\hline
\end{tabular}

Note $n=192$ Scheffé analysis of vanance, grouped mean scores

${ }^{*} p \leq 05$, ethnic group differences

${ }^{* *} p \leq 01$

The teacher scale of leadership was only marginally correlated with observers' ratings, $r=186, p \leq 05$, (see Table 3) Student ratings of influence after the interaction game were more highly correlated with teacher ratıngs of leadershıp, $r=310, p \leq 001$ The observer's ratıngs were also correlated with the students' ratings of influence after the game, $r=383$, $p \leq 001$

\section{Pre-game Status Varıables}

Students were asked prior to the beginning of the game session to give a pre-game ranking to each player, including themselves Based on their interaction in prior school or neighborhood activities, they assigned each group member to one of six positions (values indicated in parentheses) deck hand (1), cook (2), communications officer (3), medical officer (4), second-1n-command (5), and commander (6) Scores were summed over 
the values of all positions assigned to him or her by all members in the group, including his or her own

In the classroom prior to the game, all students completed a questionnaire with information on social class, educational and occupational aspirations, and an English word knowledge test The classroom teacher was asked to indicate, on the average, the letter grade the student would recelve that year in seven academic subjects Scores ranged from 4 (A) to 0 (F)

For the regression analysis, dummy variables were created for ethnicity, with (1) specifying Hispanic ethnicity and (0) coded for Anglos Sex was coded ( 1 ) for females and ( 0 ) for males The school status equity variable is a simple dummy indicator (school equity) of those schools in the original study having positive outcomes for minority students (with corresponding programs and staff that fit a positive status equity model) coded as (1) versus those schools that had negative outcomes for minority students (and few of the high-equity school conditions) coded as (0)

\section{RESULTS}

Nonverbal Behaviors

The initial focus of our research is on the general nonverbal behaviors of Hispanic females in comparison to their gender and ethnic peers Substantial differences do occur in nonverbal behaviors in the group setting Average scores for the raw and weighted measures (Table 1) indicate that children do vary between ethnic groups Looking at weighted scores, Hispanic females are significantly less likely than Anglo females to move themselves upward, verbally interrupt or to use enhanced horizontal space in general They were somewhat more likely to touch the resource cards No significant ethnic differences were found in their speaking time, self-touching behaviors or number of physical intrusions

Conversely, Hispanic males were more likely than their male Anglo peers to use physical intrusions and to expand their horizontal space They were also more likely to use verbal interruptions during the game When examıning the scores weighted for group times, Hispanic males also emerge as the student group most likely to touch the resource cards for the longest period of time

\section{Student Leadershıp}

Students are perceived as having varying leadership skills This is most evident in the votes after the game by other students in the group (see Table 2) In the female groups, both Anglo and Hispanic students voted signifi- 
Table 2

Mean pre-game status and leadershıp scores assıgned

\begin{tabular}{|c|c|c|c|c|c|c|}
\hline & \multicolumn{3}{|c|}{ Males } & \multicolumn{3}{|c|}{ Females } \\
\hline & Anglo & Huspanic & $F$ & Anglo & Hispanic & $F$ \\
\hline \multicolumn{7}{|c|}{ Pre-game status factors } \\
\hline Academic GPA & 2293 & 1885 & $368^{*}$ & 2271 & 2105 & 087 \\
\hline English word score & 2946 & 2141 & $594^{*}$ & 3178 & 2574 & $533^{*}$ \\
\hline Pre-game rank & 1890 & 2238 & $836^{* *}$ & 2113 & 2087 & 392 \\
\hline \multicolumn{7}{|l|}{ Leadership ratings } \\
\hline Observer scale & 4683 & 4506 & 143 & 4666 & 4551 & 125 \\
\hline Student vote & 105 & 100 & 090 & 116 & 074 & $976^{* *}$ \\
\hline Teacher scale*** & 1966 & 1733 & $458 *$ & 2283 & 2008 & $643^{*}$ \\
\hline
\end{tabular}

Note $n=192$ One-way analysis of variance

${ }^{*} p<05$ for ethnic group differences

$* * p \leq 01$

${ }^{* * *} p \leq 05$ for gender differences

cantly less often for Hispanic females than for Anglo females If we compare the pre-game student rankngs in the male groups, it is evident that Anglo males gained in the eyes of their male peers during the interaction game Anglo males moved from a lower average pre-game rankıng than Huspanic males to similar average leadership votes when the game was concluded Overall, the female groups did not have significant differences in pre-game rankings, but after the game, Anglo females' scores were increased significantly above those of Hispanic females The traned observers, however, did not find significant differences by gender or ethnicity in the leadership skalls exhibited by students during the interaction game itself

\section{Leadershıp and Status Varıables}

We first consider the range of status indicators for students as they are correlated to the two independent observations of group leadership (see Table 3) Students' and trained observers' leadership ratings are independent of ethnicity or the school equity variable Students' ratings of leadership are significantly correlated with the educational status factors, grade point average and English word knowledge and the pre-game student rankıng Interestıngly, observers' ratıngs are unrelated to grades, but are significantly correlated with Englısh word knowledge

The classroom teachers, who did not view the interaction game, assigned students a leadership score from classroom observations In this case, we can examine the independent effects of gender, along with other status factors Teachers' ratings of leadership are significantly correlated 
Table 3

Correlations of pre-game status and nonverbal behaviors with leadership ratings

\begin{tabular}{|c|c|c|c|}
\hline \multirow[b]{2}{*}{ Varnable } & \multicolumn{3}{|c|}{ Leadershıp Ratıngs } \\
\hline & Observer & Student & Teacher \\
\hline \multicolumn{4}{|l|}{ Pre-game status factors } \\
\hline Hispanic ethnicity & -066 & -073 & $-225^{* *}$ \\
\hline School equity & -013 & 002 & 065 \\
\hline Female sex & - & - & $264^{* * *}$ \\
\hline Hispanic/school & -001 & -045 & -082 \\
\hline Hispanic/sex & - & - & $132 *$ \\
\hline Academic GPA & 079 & $336 * * *$ & $406^{* * *}$ \\
\hline Word knowledge & $252 * *$ & $209 * *$ & $591 * * *$ \\
\hline Pre-game student rank & - & $477 * * *$ & - \\
\hline \multicolumn{4}{|l|}{ Nonverbal behaviors } \\
\hline Physical intrusions & $315 * * *$ & $183 * * *$ & 044 \\
\hline Verbal interruptions & 108 & 054 & $382 * * *$ \\
\hline Upward movement & 095 & 109 & -019 \\
\hline Horizontal movement & $341^{* * *}$ & $243^{* * *}$ & $149 *$ \\
\hline Self comforting & $-307 * * *$ & $152^{*}$ & $-142^{*}$ \\
\hline Speakıng time & $585^{* * *}$ & $462 * * *$ & $177^{*}$ \\
\hline Resource cards & $452 * * *$ & $513 * * *$ & 093 \\
\hline
\end{tabular}

with ethmicity, gender, and the interaction term for these two vanables, such that teachers are significantly more likely to rate Anglos and females as having leadership skills Leadership ratıngs by teachers are substantially correlated with the educational factors grade point average and English word knowledge scores Anglo females, who scored highest on these two factors overall, are rated as having the highest leadership qualities by their teachers

\section{Leadership and Nonverbal Behaviors}

Leadership ratings are correlated with the full range of nonverbal behav1ors, and in the expected directions The time speaking and amount of time controlling resource cards are highly correlated with the leadership ratıngs by both students and direct observers The physical and verbal interruption rates are correlated positively with leadership scores, as are the measures of expanded personal space Evidently, students and direct observers are influenced in their ratings of leadership by the nonverbal behaviors of students in the interaction setting This fits the adult model of leadership, power, and status in the literature As Henley (1977) posits, self-comforting 
behaviors are negatively correlated with observer and student ratıngs of leadership The only nonverbal behavior which is uncorrelated with leadership rating is the indicator of upward movement It is quite possible that elevation above the game board is confounded by size, which at this age may vary considerably withın ethnic and gender groupings

Teacher ratings and nonverbal behaviors Consistency of leadership ratings among teachers, observers, and students may occur if students have a generalized presentation of themselves within the classroom which overlaps with behaviors used in the interaction game We find positive correlations of teachers' leadership ratıngs with speaking time and use of personal space The self-comforting measure is negatively correlated with ratings by teachers

\section{PREDICTING LEADERSHIP}

In Tables 4 to 6 , we predict the leadership scores assigned to students by trained observers, peers in the interaction game, and finally their classroom teachers We used regression analysis (ordinary least squares) to examine the combined effects of nonverbal behaviors, status factors, and the

\section{Table 4}

Regression analysis of observer ratıng of student leadership

\begin{tabular}{|c|c|c|}
\hline Vanables & $\begin{array}{c}\text { Males } \\
(n=74) \\
\text { Beta }\end{array}$ & $\begin{array}{c}\text { Females } \\
(n=62) \\
\text { Beta }\end{array}$ \\
\hline Hispanic ethnicity & 01 & -068 \\
\hline School equity & 058 & -048 \\
\hline Hispanic school & -045 & 196 \\
\hline Word knowledge & 196 & -067 \\
\hline Academic GPA & -054 & -116 \\
\hline Physical intrusions & -047 & -034 \\
\hline Verbal interruptions & -168 & 152 \\
\hline Upward movement & 059 & 154 \\
\hline Horizontal movement & 190 & 181 \\
\hline Self-comfortung & $-230^{*}$ & 009 \\
\hline Speakang time & $498^{* * *}$ & $373^{*}$ \\
\hline Resource cards & 166 & 063 \\
\hline Constant & 3167 & 3808 \\
\hline$R^{2}$ & 58 & 45 \\
\hline Adyusted $R^{2}$ & 48 & 28 \\
\hline$F$ & $557 * * *$ & $275^{* *}$ \\
\hline
\end{tabular}


Table 5

\begin{tabular}{|c|c|c|}
\hline Tanable & $\begin{array}{c}\text { Male } \\
\text { Beta }\end{array}$ & $\begin{array}{c}\text { Female } \\
\text { Beta }\end{array}$ \\
\hline Iispanic ethnicity & -015 & 054 \\
\hline chool equity & 113 & $278^{*}$ \\
\hline Hispanic school & -028 & $-298^{*}$ \\
\hline tudent ranking & $284^{*}$ & $222^{*}$ \\
\hline Vord knowledge & -010 & $238^{*}$ \\
\hline cademic GPA & $329^{* *}$ & $193^{*}$ \\
\hline hysical intrusions & -145 & $-224^{*}$ \\
\hline erbal interruptions & -063 & -046 \\
\hline Jpward movement & $266^{*}$ & -101 \\
\hline forizontal movement & 027 & $207^{*}$ \\
\hline elf-comforting & 022 & -098 \\
\hline peakıng tıme & $273^{*}$ & $442^{* * *}$ \\
\hline Resource cards & $334 * *$ & 162 \\
\hline Constant & 225 & 352 \\
\hline$R^{2}$ & 54 & 74 \\
\hline Adjusted $R^{2}$ & 43 & 67 \\
\hline$F$ & $515^{* * *}$ & $978^{* * *}$ \\
\hline
\end{tabular}

school setting All predictor variables were entered simultaneously, separately by gender

\section{Observer Ratıngs}

The observer's ratıngs of leadership for both males and females were predominantly related to speaking time In addition, leadership scores for males were negatively related to self-touching behavior Each equation explains substantial variance in the leadershıp scores assigned to male students, $R^{2}=58, p \leq .001$, and female students, $R^{2}=45, p \leq 01$ None of the pre-game status factors are significantly related to the leadership ratings of the students, indicating that observed leadership occurs at equal rates in all educational settings and across all ethnic groups

Peer Ratıngs

Peers' leadership ratings, on the other hand, were highly related to the initial crew position they assigned to the other students prior to the game The higher this initial student ranking, the higher the student's final leadership votes Higher academic grade point averages and speaking time also generally predicted higher leadership scores assigned by students

For male students, the equation predicting leadership scores also shows 
significant influence of upward movement and control of the resource cards None of the ethnic, school equity, or English word knowledge factors contribute to predicting these scores The equation explains over one half of the variance in leadership scores, $R^{2}=54, p \leq 001$

Female peer ratıngs of leadership also are related to factors beyond academic and pre-game crew assignments Greater time speaking and use of horizontal space were associated with more votes of leadership In contrast, physical intrusions by females were related to lower leadership votes awarded to them by other group members, regardless of ethnicity The school equity factor has a significant simple correlation, and an interaction effect with Hispanic ethnicity When the interaction term is removed from the equation, the percent of variance explained drops substantially, from $742(p \leq 001)$ to $586(p \leq 01)$ The direction of the beta indicates that Hispanic females in high-equity schools are given more votes for leadership, when controlling for other academic, social and behavioral scores

\section{Teacher Ratıngs}

Classroom teacher ratıngs of general student leadership were straightforward and powerful, explaining over half of the variance in the scores (see Table 6) The equations for both male and female students were dominated by English word knowledge and the school equity vanable Evident-

\section{Table 6}

Regression analysis of teacher ratung of student leadership

\begin{tabular}{|c|c|c|}
\hline Vanable & $\begin{array}{l}\text { Male } \\
\text { Beta }\end{array}$ & $\begin{array}{c}\text { Female } \\
\text { Beta }\end{array}$ \\
\hline $\begin{array}{l}\text { Hispanic ethnicity } \\
\text { School equity } \\
\text { Hispanic school } \\
\text { Word knowledge } \\
\text { Academic GPA } \\
\text { Physical intrusions } \\
\text { Verbal interruptions } \\
\text { Upward movement } \\
\text { Horizontal movement } \\
\text { Self-comforting } \\
\text { Speaking time } \\
\text { Resource cards } \\
\quad \text { Constant } \\
R^{2} \\
\text { Adjusted } R^{2} \\
F\end{array}$ & $\begin{array}{l}026 \\
349^{*} \\
021 \\
560^{* * *} \\
062 \\
-241 \\
330^{* *} \\
129 \\
168 \\
-063 \\
-176 \\
029 \\
425 \\
54 \\
41 \\
446^{* * *}\end{array}$ & $\begin{array}{l}047 \\
344^{*} \\
-247 \\
515^{* * *} \\
111 \\
-104 \\
172 \\
-189 \\
113 \\
-016 \\
095 \\
-083 \\
574 \\
.52 \\
38 \\
369 * * *\end{array}$ \\
\hline
\end{tabular}


ly, teachers in the high-equity schools saw more leadership overall in their students, when compared with teachers rating students with similar skills and backgrounds in low-equity schools In the prediction equation for males, verbal interruption rates, a classic dominance indicator, contributed to explained variance in the leadership scores

\section{DISCUSSION}

The assessment of leadership and the nonverbal behaviors of Hispanic females across varynng desegregated schools is a complex theoretical and methodological effort Each of the status factors had significant import for predicting female student ratings of leadership, but had little predictive power for male student ratings Female students gave Hispanic females the lowest average leadership scores, even when behavioral and academic factors were controlled Female peers also significantly downgraded leadership scores for physical intrusions, while male equations showed no effects from this variable For both males and females, the leadership skill ratıngs were related to the pre-game status of the student Research indicating that Hispanic females are often at the bottom of a school status hierarchy emphasizes the importance of these findings In light of these factors, we reemphasize the finding that student leadership rankings for Hispanic females overall were related to attendance at a high-equity, integrated school

In contrast, observer ratings of leadership were relatively unrelated to status factors Many nonverbal factors were correlated with observer leadership ratıngs, but in the regression analysis the primary predictor of leadership was speaking time This factor was one of only two measured variables (along with touching of the resource cards) that did not vary significantly by ethnicity Evidently the observers did not hold to traditional ethnic or sex-role expectations for leadership, and this may reflect the deliberate ethnic and gender mix of the observers This finding reinforces the equal status relations model posited by Berger, Conner, and Fisek (1974) and the prior research findings by Iadicola and Moore (1983) on gender and ethnic equity models for educational staff

Teacher ratıngs of student leadership were very sensitive to a number of the pre-game status factors They tended to rank female students higher overall and this is likely due to the higher English word knowledge scores of female elementary school students in general As shown in Table 6, the school status equity score was independently and positively associated with higher teachers' leadership scores for both male and female students, regardless of ethnicity This suggests that Hispanic females and their Hispanic male peers benefit not only in the evaluations of their peers at highequity schools, but in their teachers' evaluations as well Given the distinct cultural and gender patterns of leadership displayed by students, we con- 
clude that Hispanic females in particular, and students in general, have enhanced educational and leadership opportunities in high-equity, integrated elementary schools

The results show that students of this age definitely vary in their use of nonverbal behaviors, with distinct gender and ethnic patterns emerging Hispanic females are less expansive in their use of vertical and horizontal personal space than their peers They are also less likely to interrupt or intrude However, they showed no difference in use of self-comforting behaviors and they held their own in terms of speaking time and touching of the resource cards when interacting with Anglo females Hispanic females are doing a fair share of handling resources and providing group leadership, not through the dominance cues of expanded personal space and physical or verbal intrusions, but by keeping their hands on the cards and participating in the discussion

Nonverbal behaviors are used as criteria for leadership rankıngs by students and independent observers The patterns for this age group parallel those for adults physical touch, expansion, and physical or verbal dom1nance in the game are associated with higher ratıngs of leadership, whereas self-comfortıng behaviors are related to lower ratings However, for student ratıngs of leadership, these relationships are affected by pre-game status factors, including ethnicity and the school equity environment

One serious consideration for the behavioral and leadership findings is that these are displayed and rated (with the exceptions of teachers) in gender-segregated game settings It is likely that students in a mixed-gender, task-oriented, cooperative group will revert to traditional sex-role expectations and that Hispanic and Anglo female behaviors and leadership ratings will be substantially altered However, our research does give us some insight into the potential leadership and nonverbal behavior patterns of students, both male and female, especially in supportive educational settıngs

One of our most important policy-relevant findings has to do with leadership ratıngs within the schools Teacher and student peer ratings are affected by the pre-game status variables of students, including academic and social factors These factors are mediated by the school equity environment, with high-equity schools providing the most positıve setting for the evaluation of Hispanic female leadershıp For the independent observers, the potential for leadership exists in both high- and low-equity schools and for both ethnic groups Our goal is to enhance educational and leadership opportunities for Hispanic females and their student peers by providing more information about the positive effects of high-equity school settings

\section{REFERENCES}

Aiello, J R , \& Jones, S E (1971) Field study of the proxemic behavior of young school children in three subcultural groups Journal of Personality and Social Psychology, 19, 351-356 
Anes, E (1982) Verbal and non-verbal behavior in single-sex and mixed-sex groups Psychological Reports, 51, 127-134

Baxter, J C (1970) Interpersonal spacing in natural settings Sociometry, 33, 444-456

Berezaulce-Mulcahy, E (1980) Latınas in educational leadership Chicago, Illınos In Natronal Institute of Education, Conference on educational and occupational needs of Hispanic women (pp 75-86) Washington, DC National Institute of Education

Berger, J , Conner, T L, \& Fisek, M H (1974) Expectations states theory A theoretical research program Cambridge, MA Winthrop

Berger, J, Rosenholtz, S J , \& Zeldtıch, M Jr (1980) Status organızıng processes Annual Review of Soctology, 6, 479-508

Cohen, E (1984) The desegregated school Problems in status power and interethnic climate In N Muller and M B Brewer (Eds), Groups in contact The psychology of desegregatron (pp 77-96) New York Academic

Frieze, I , \& Ramsey, S J (1976) Nonverbal maintenance of traditional sex roles Journal of Socual Issues, 32, 133-141

Henley, N M (1973) Status and sex Some touching observations Bulletın of the Psychonomic Socuety, 2, 91-93

Henley, N M (1977) Body politics Englewood Cliffs, NJ Prentice-Hall

Iadicola, P, \& Moore, H A (1983) The desegregated school and status relations among Hispanic and Anglo students The dilemma of school desegregation Aztlan International Journal of Chicano Studies, 14, 39-58

Iadicola, P, Lewis, J , Moore, H , \& Nickles, H (1978) Study of effective multiethnic schools technucal manual Riverside, CA PRIME

Johnson, D W , Johnson, R , \& Maruyama, G (1984) Goal inter-dependence and interpersonal attraction in heterogeneous groups $\mathrm{A}$ metanalysis In $\mathrm{N}$ Miller \& $\mathrm{M}$ Brewer (Eds), Groups in contact The psychology of school desegregation (pp 187-213) New York Academic

Jones, S E (1971) A comparative proxemics analysis of dyadic interaction in selected subcultures of New York City Journal of Social Psychology, 84, 35-44

Lockheed, M E (1976) The modification of female leadership behavior in the presence of males Princeton, NJ Educational Testing Service PR 76-28

Mayo, C , \& Henley, N (Eds) (1981) Gender and nonverbal behavior New York SpringerVerlag

Mehrabian, A (1972) Verbal and nonverbal interaction of strangers in a wating situation Journal of Experimental Research in Personality, 5, 127-138

Mercer, J R, Iadicola, P, \& Moore, H (1980) Building effective multiethnic schools Evolving models and paradigms In W G Stephan and J R Feagin (Eds), School desegregation Past, present and future (pp 281-304) New York Plenum

Mirande, A , \& Enriquez, E (1979) La Chicana The Mexican-American woman Chicago University of Chicago Press

Moore, H A (1983) Hispanic women Schooling for conformity in public education Hispanic Journal of Behavioral Scrences, 5, 45-63

Pearson, J C (1985) Gender and communication Dubuque, IA Brown

Ridgeway, C (1987) Nonverbal behavior, dominance and the basis of status in task groups American Soctological Review, 52, 683-694

Rosenfield, D, \& Stephan, W G (1981) Intergroup relations among children In S S Brehm, S M Kassin, \& F X Gibbons (Eds), Developmental social psychology (pp 271-297) New York Oxford University Press

Schwartz, B , Tesser, A , \& Powell, E (1982) Dominance cues in nonverbal behavior Socral Psychology Quarterly, 45, 114-120

Simoniello, $K$ (1981) On investigating the attitudes toward success and achievement in professional U S Mexican American women Aztlan International Journal of Chicano Studies, 12, 121-137

Strodtbeck, F L , \& Mann, R D (1956) Sex differentiation in jury delıberation Sociometry, 19, 3-11 
Zapata, J T, and Jaramillo P T (1981) The Mexican American family An Adlerian perspective Hispanic Journal of Behavioral Sctences, 3, 275-290

Zımmerman, D H , \& West, C (1975) Sex roles, interruptions, and silences in conversation In B Thorne and $\mathrm{N}$ Henley (Eds), Language and sex Difference and Dominance Rowley, MA Newbury House

First draft received December 22, 1986

Final draft received November 25, 1987 